PAWEŁ OLSZEWSKI

Instytut Studiów Politycznych PAN

ORCID: 0000-0002-7539-1224

olszewskipaw@gmail.com

\title{
Green Deal a Zielona Agenda dla Bałkanów Zachodnich
}

Green Deal and the Green Agenda for the Western Balkans

Słowa kluczowe:

Zielony Ład, Zielona

Agenda, Bałkany
Keywords:

Green Deal, Green

Agenda, Balkans 


\section{Green Deal and the Green Agenda for the Western Balkans}

This article deals with the important topic of the Green Agenda for the Western Balkans and its place in the perspective of the so-called Green Deal of the European Union. The author discusses the issue of the green deal and agenda from the perspective of the Union's foreign policy and the process of adaptation of the Balkans in the integration process. The topic of the participation of the Western Balkans in the pro-ecological activities of the European Union is based on a collective document presented in 2019 by the European Union as the Green Deal, setting new directions for the development of EU policy. The countries of the Western Balkans have dealt with this issue extensively in the document entitled "Sofia Declaration for the implementation of the Green Agenda for the Western Balkans". Their activities in this area are related not only to the fulfillment of assumptions regarding environmental protection but also in the context of the potential enlargement of the European Union and the willingness to join the group of Member States. In this regard, the Balkan states perceive the Green Agenda as a broader spectrum of their functioning in united Europe and the possibility of appearing on the European arena by fitting into the pan-European trend. The complexity of these processes is extremely large and covers several aspects, the implementation of which is possible not only with the support of the European Union but above all as part of the development of regional cooperation. 
/ omisja Europejska w 2019 r. zaprezentowała Europejski Zielony Ład, czyli Mpakiet rozwiązań mających na celu zrównoważenie gospodarki państw członkowskich $\mathrm{w}$ aspekcie ochrony środowiska, jak również zmiany energetycznej. Dokument przedstawia cały szereg rozwiązań proekologicznych obejmujących inwestycje wspomagające rozwój środowiska naturalnego i prowadzących do ograniczenia degradacji środowiska naturalnego. Jednym z jego założeń jest nie tylko rozwój zielonych technologii i oǵraniczenie emisji gazów cieplarnianych, lecz także podniesienie poziomu finansowania badań $\mathrm{z}$ tego zakresu. Na temat Zielonego Ładu wypowiedział się wiceprzewodniczący wykonawczy Komisji Europejskiej Frans Timmermans: „[...] mamy do czynienia z kryzysem klimatycznym i ekologicznym. Europejski Zielony Ład stwarza szansę na poprawę zdrowia i dobrostanu Europejczyków dzięki transformacji naszego modelu gospodarczego. W naszym planie przedstawiliśmy, w jaki sposób ograniczyć emisje, uzdrowić nasze środowisko naturalne, chronić dziką faunę i florę, stworzyć nowe możliwości gospodarcze i poprawić jakość życia obywateli. Wszyscy mamy do odegrania ważną rolę, a proces transformacji obejmie każdy sektor przemysłu i każde państwo. Co więcej, spoczywa na nas odpowiedzialność, aby transformacja była sprawiedliwa i aby w trakcie realizacji Europejskiego Zielonego Ładu nikt nie pozostał w tyle" ${ }^{\prime 1}$,Zielony Ład jest u podstaw wysiłkiem na rzecz przekształcenia europejskiej gospodarki i europejskich wzorców konsumpcji. Ale ponieważ pociąga za sobą fundamentalną przebudowę europejskiego systemu energetycznego i ponieważ zajmuje tak wysokie miejsce $\mathrm{w}$ agendzie polityki UE, zmieni również relacje między UE a jej sąsiedztwem i przedefiniuje wcześniej stosowaną globalną politykę Europy"2. Można stwierdzić, że jest to swoisty rodzaj działań w zakresie polityki zagranicznej Unii Europejskiej i próba oddziaływania w szerszym zakresie za pomocą miękkiej siły obudowanej w ramy proekologiczne, dające także realną szansę na zmiany nie tylko środowiska naturalnego, lecz także rekonstrukcję europejskiej i w dalszej perspektywie globalnej polityki energetycznej, w tym modyfikacji źródeł energii.

1 Europejski Zielony Ład, Komisja Europejska, Przedstawicielstwo w Polsce, 11 XII 2019 [dostęp: 17 VII 2021]: 〈https://ec.europa.eu/poland/news/191211_green_deal_pl〉.

2 M. Leonard, J. Pisani-Ferry, J. Shapiro, S. Tagliapietra, G. Wolff, The geopolitics of the European Green Deal, "Policy Contribution" 2021, issue 04: <https://www.bruegel. org/wp-content/uploads/2021/o2/PC-O4-GrenDeal-2021-1.pdf > [dostęp: 21 VII 2021]. 
„UE importowała w 2019 r. produkty energetyczne o wartości ponad 320 mld euro, a ponad 60\% importu UE z Rosji stanowily produkty energetyczne. Ogromna redukcja w tym procencie zrestrukturyzuje stosunki UE z kluczowymi dostawcami energii. Kraje, w tym Rosja, Algieria Norwegia zostaną ostatecznie pozbawione swojego głównego rynku eksportowego. Nieuchronnie wyjście Europy z uzależnienia od paliw kopalnych wpłynie negatywnie na wielu partnerów regionalnych, a nawet może ich zdestabilizować gospodarczo i politycznie. Po drugie, Europa odpowiada za około $20 \%$ światowego importu ropy naftowej. Spadek popytu na ropę wynikający z przejścia Europy na odnawialne źródła energii wpłynie na światowy rynek ropy, obniżając ceny i zmniejszając dochody głównych eksporterów, nawet jeśli nie handlują zbyt dużo z UE. Po trzecie, bardziej ekologiczna Europa będzie bardziej zależna od importu produktów i surowców, które służą jako nakłady na czystą energię i czyste technologie. Na przykład pierwiastki ziem rzadkich, których Chiny są największym producentem, są niezbędne do produkcji baterii. Co więcej, Europa mogłaby pozostać głównym importerem energii netto, ale energia ta będzie musiała być zielona, jak na przykład zielony wodór produkowany w bogatych w słońce częściach świata. Po czwarte, Zielony Ład wpłynie na międzynarodową konkurencyjność Europy. Jeśli europejskie przedsiębiorstwa poniosą koszty związane z regulacjami, których nie ponoszą ich zagraniczni konkurenci, staną się mniej konkurencyjne zarówno w kraju, jak i za granicą. A jeśli UE spróbuje ograniczyć tę stratę i uniknąć ucieczki emisji, nakładając taryfy na import o dużej zawartości węgla, ryzykuje oskarżenie o zakłócanie handlu międzynarodowego, co może prowadzić do tarć z głównymi partnerami handlowymi, szczególnie wysokoemisyjnymi, jeśli postrzegają oni mechanizm dostosowania granic emisji dwutlenku węgla jako nielegalną barierę handlową"3.

Europa odpowiada tylko za mniej niż 10\% światowej emisji gazów cieplarnianych, dlatego jej wysiłki nie będą istotnym wkładem w politykę ochrony środowiska naturalnego. Stanie się jednak nie tylko prekursorem nowych rozwiązań, lecz także podmiotem na arenie międzynarodowej, który może zacząć odǵrywać znaczącą rolę w kształtowaniu pozycji innych państw na arenie globalnej, jak i rozwijać najnowsze technologie, co może z niej uczynić wysoko specjalistyczny region pod kątem funkcjonowania społeczeństw. Niestety zmiany wywołane poprzez przekształcenie polityki energetycznej

\section{Tamże.}


mogą się przyczynić do wzrostu cen w Unii Europejskiej, ale z drugiej strony mogą spowodować wykreowanie nowoczesnych technologii produkcji. Tym samym państwa członkowskie mogą przejść głęboką metamorfozę, wchodząc w XXI wiek jako te o najwyższym wskaźniku nowoczesności. Po części byłoby to także elementem wypełniania założeń postanowień zawartych w programie Europa 2020, zarówno w aspekcie technologicznym, społecznym, jak i edukacyjnym. Unia Europejska dzięki wdrożeniu Zielonego Ładu stanie się głównym inspiratorem zmian globalnych, wywierającym naciski na inne państwa i regiony w kontekście odchodzenia od paliw kopalnych. W związku z powyższym Komisja Europejska już uznała, że może wybrać jedynie dwie drogi takiego oddziaływania - albo poprzez eksport norm i zachęcanie do ich stosowania, albo poprzez wzmacnianie tzw. hard Edge, czyli rozgraniczenia między nią a pozostałymi podmiotami międzynarodowymi w celu ochrony przyjętych założeń. O ile eksport norm nie jest niczym złym, choć może się okazać zupełnie nieskuteczny, zwłaszcza w perspektywie małej siły oddziaływania UE na arenie globalnej, to zamykanie i uszczelnianie granic oraz swojej polityki może doprowadzić do izolacji lub samoizolacji, która z kolei będzie wymagała niezwykle szerokiej samodzielności i samowystarczalności. Taki scenariusz w dzisiejszym wysoce zglobalizowanym świecie praktycznie nie ma możliwości spełnienia. Jednak ze wzğlędu na zaplanowane działania i przyjęte rozwiązania Unia Europejska powoli, aczkolwiek sukcesywnie, będzie wycofywała się z obecnie aktywnych umów handlowych, co wymusi nowe negocjacje, będzie ograniczała inwestycje zewnętrzne nieobejmujące zielonych technologii, a tym samym zacznie ograniczać swoją produkcję, rynek zbytu i możliwe, że tym samym własną siłę nabywczą. Pojawią się także wyzwania i problemy w relacjach międzynarodowych, wynikające głównie z finalizacji umów handlowych z Rosją i państwami Zatoki Perskiej, a możliwym wzmacnianiem relacji z państwami dostarczającymi surowce do produkcji proekologicznej. Takim beneficjentem w tym zakresie mogą być Chiny. Ograniczenie zapotrzebowania Unii Europejskiej na import surowców energetycznych odczują także Stany Zjednoczone, z których według danych Eurostatu importowane jest $17,7 \%$ paliw stałych ${ }^{4}$ niezbędnych do zabezpieczenia potrzeb energetycznych Unii Europejskiej. Państwem, które może stracić najwięcej

4 From where do we import energy??, Eurostat [online], 3 II 2021 [dostęp: 17 VII 2021]: <https://ec.europa.eu/eurostat/cache/infographs/energy/bloc-2c.html\#carousel Controls?lang $=\mathrm{en}>$. 
na polityce unijnej, jest Federacja Rosyjska, która pokrywa 26,9\% zapotrzebowania UE na rope, $46,7 \%$ zapotrzebowania na paliwa stałe i $41,1 \%$ zapotrzebowania na gaz naturalny ${ }^{5}$, co może prowadzić zarówno do zmiany kierunku polityki handlowej Rosji, jak i do narastania napięć pomiędzy oboma podmiotami. Pod tym kątem Zielony Ład jest niewątpliwie założeniem wysokokonfliktowym i zaburzającym współpracę, co więcej, przekłada się wprost na pozycję międzynarodową Unii Europejskiej, która poprzez takie działania może zdecydowanie osłabić lub wzmocnić swoją pozycję. Nie da się obecnie przejrzyście określić, jaką będzie pozycja Unii po pełnym wdrożeniu programu. Równie ważnym aspektem jest nastawienie państw członkowskich, które bez odpowiedniego wsparcia nie będą gotowe do tak radykalnych zmian, prowadzących m.in. do zubożenia ich sektorów wydobycia, produkcji; szerokich zmian w polityce zatrudnieniowej i do wzrostu uzależnienia od największych europejskich producentów tzw. zielonej energiii. Powstaje także pytanie, w jakim zakresie i z jaką siłą UE będzie oddziaływała na najbliższe sąsiedztwo, w tym na państwa znajdujące się na Bałkanach Zachodnich?

\section{Bałkany Zachodnie a Zielony Ład}

„Zewnętrzny wymiar Europejskiego Zielonego Ładu najlepiej ilustruje kilka strategii regionalnych, które przedstawiają ambicje UE dotyczące jej działań zewnętrznych na Bałkanach Zachodnich, w sąsiedztwie UE i Afryce. Te strategie regionalne, $\mathrm{w}$ połączeniu z bieżącym programowaniem Instrumentu Pomocy Przedakcesyjnej (IPA) oraz Instrumentu Sąsiedztwa, Rozwoju i Współpracy Międzynarodowej na rzecz Globalnej Europy (Neighbourhood, Development and International Cooperation Instrument, NDICI), wykazują oparte na współpracy podejście do budowania zewnętrznego wymiaru Europejskiego Zielonego Ładu poprzez programowanie inwestycji i rozwoju. Inicjatywy te są często oparte na lokalnych zainteresowaniach i potrzebach, a zatem wykazują dużą różnorodnośćn

5 Tamże.

6 C. Teevan, A. Medinilla, K. Sergejeff, The Green Deal in EU foreign and development policy, European Centre for Development Policy Management, Maastricht 2021 (Briefing Note, No. 131): 〈https://ecdpm.org/wp-content/uploads/Green-Deal-EU-ForeignDevelopment-Policy-ECDPM-Briefing-Note-131-2021.pdf> [dostęp: 17 VII 2021]. Wszystkie cytaty z opracowań i dokumentów anglojęzycznych w tłumaczeniu autora. 
Bałkany Zachodnie, jako region niezwykle skomplikowany, pozostają w strefie szczególnego zainteresowania Unii Europejskiej i państw członkowskich, co jasno wyraziła Ursula von der Leyen w swoim orędziu o stanie Unii z dnia 14 września 2020 r., „przyszłość całego tego regionu leży w Unii Europejskiej" ${ }^{j}$. Pamięć o wojnie z lat 90. XX w., obecna w przestrzeni europejskiej, inspiruje aktywność UE w regionie. Unia Europejska podejmuje od lat 90. działania stabilizacyjne, urguntowujące procesy demokratyzacyjne i co najważniejsze, działa na rzecz zbliżenia państw regionu Bałkanów Zachodnich do europejskiej przestrzeni. Zakres tych aktywności obejmuje wszelkie procesy związane z integracją i docelowym członkostwem tychże państw w strukturach UE. Konieczność utrzymania pokojowych relacji w regionie i wzajemnego pozytywnego oddziaływania spowodowała, że również Zielony Ład znalazł tu swoje odzwierciedlenie, jako element wzmacniający obopólną zależność, gwarantujący uniezależnienie od źródeł energii importowanych z państw trzecich oraz ujednolicający politykę energetyczną na terytorium Europy. W Komunikacie Komisji do Parlamentu Europejskiego, Rady Europejskiej, Rady, Komitetu EkonomicznoSpołecznego i Komitetu Regionów Europejski Zielony Ład ${ }^{8}$ podkreślono znaczenie regionu Bałkanów Zachodnich w powyższym programie: „UE będzie kładła nacisk na wspieranie jej bezpośrednich sąsiadów. Zielona transformacja dla Europy może być w pełni skuteczna tylko wtedy, gdy bezpośrednie sąsiedztwo UE również podejmie skuteczne działania. Trwają prace nad zielonym programem działań dla Bałkanów Zachodnich. Komisja i Wysoki Przedstawiciel planują również szereg silnych partnerstw $\mathrm{w}$ dziedzinie środowiska, energii i klimatu zawartych z południowym sąsiedztwem oraz w ramach Partnerstwa Wschodniego" ${ }^{\prime \prime}$. Potwierdza to dokument Komisji

7 Komunikat Komisji do Parlamentu Europejskiego, Rady, Europejskiego Komitetu Ekonomiczno-Społecznego i Komitetu Regionów, Plan gospodarczo-inwestycyjny dla Bałkanów Zachodnich, [swD(2020) 223 final], Bruksela, 6 X 2020, $\operatorname{com}(2020)$ 641 final.

8 Europejski Zielony Ład, Komunikat Komisji do Parlamentu Europejskiego, Rady Europejskiej, Rady, Komitetu Ekonomiczno-Społecznego i Komitetu Regionów, $\operatorname{com}(2019) 640$ final, Komisja Europejska, Bruksela 2019, s. 2: <https://eur-lex. europa.eu/resource.html?uri=cellar:b828d165-1c22-11ea-8c1f-o1aa75ed71a1.0016.02/ DOC_1\&format=PDF> [dostęp: 17 VII 2021].

9 Tamże. 
Europejskiej zatytułowany Guidelines for the Implementation of the Green Agenda for the Western Balkans, czyli Wytyczne dla wdrożenia Zielonego Ładu na Bałkanach Zachodnich, który został wsparty projektem wyrażonym $\mathrm{w}$ dokumencie Communication from the Commission to the European Parliament, the Council, the European Economic and Social Committee and the Committee of the Regions An Economic and Investment Plan for the Western Balkans, czyli Komunikat Komisji do Parlamentu Europejskiego, Rady, Europejskiego Komitetu Ekonomiczno-Społecznego i Komitetu Regionów Plan gospodarczy i inwestycyjny dla Bałkanów Zachodnich.

W tym dokumencie zawierającym wytyczne dotyczące wdrożenia Zielonego Ładu na Bałkanach przedstawiono pięć głównych elementów strategii w regionie, to jest: aktywność w zakresie dekarbonizacji, rozwoju polityki energetycznej i mobilności, gospodarka skupiona na odpadach, recyklingu, bioróżnorodność, zmniejszanie zanieczyszczeń, wdrażanie zrównoważonych systemów żywieniowych. Cyfryzacja będzie kluczowym czynnikiem umożliwiającym realizację tych pięciu filarów zgodnie $\mathrm{z}$ koncepcją podwójnej transformacji ekologicznej i cyfrowej. Cele powinny być realizowane w ramach wyznaczonych mechanizmów i instrumentów finansowych. „Współpraca polityczna i zapewnienie realnych alternatyw dla paliw kopalnych mogą mieć kluczowe znaczenie dla pomocy krajom partnerskim w ponownym rozważeniu niezrównoważonych inwestycji infrastrukturalnych i energetycznych. Aby wykorzystać ogromny potencjał nowego modelu gospodarczego opartego na zrównoważeniu i neutralności klimatycznej, potrzebna będzie pomoc techniczna i finansowa. Zmiany klimatyczne będą nadal powodować znaczny stres w Europie pomimo wysiłków łagodzących. Dlatego kluczowe znaczenie ma wzmocnienie wysiłków na rzecz uodpornienia na zmiany klimatu, budowania odporności, zapobiegania i gotowości w regionie. Powinna ona obejmować zaangażowanie sektora prywatnego $\mathrm{w}$ inwestycje w odporność oraz opracowanie mechanizmów transferu ryzyka związanego z klęskami żywiołowymi. Pojawia się szeroki konsensus, że ceny emisji dwutlenku węgla będą ważnym instrumentem w osiąganiu celów klimatycznych. Można zbadać możliwość wczesnego włączenia Bałkanów Zachodnich do systemu handlu uprawnieniami do emisji. Może to być kluczowe narzędzie do tworzenia zachęt ekonomicznych do działań na rzecz klimatu i ułatwienia przejścia na neutralność klimatyczną. Przejście na neutralność klimatyczną, aby odnieść sukces, musi być sprawiedliwe społecznie i sprzyjać włączeniu społecznemu. 
Należy uznać, że nie wszystkie kraje lub regiony rozpoczynają transformację $\mathrm{z}$ tego samego punktu lub mają taką samą zdolność do reagowania. Można by zbadać system odpowiadający europejskiemu mechanizmowi sprawiedliwej transformacji przewidzianemu w Europejskim Zielonym Ładzie. Te zmiany będą wymagały poparcia obywateli. Według sondażu 93\% obywateli UE uważa zmianę klimatu za poważny problem. Podobne badanie przeprowadzone na Bałkanach Zachodnich w 2019 r. wykazało, że tylko $65 \%$ populacji regionu uważa zmiany klimatyczne za zagrożenie. Rozszerzony na ten region Europejski Pakt Klimatyczny może być narzędziem zwiększania świadomości i zapewniania poparcia społeczeństwa obywatelskiego i jednostki"10.

Unia Europejska zdaje sobie sprawę z konieczności wdrożenia programów finansowych w celu wspomagania procesów rozwoju Zielonej Agendy w regionie Bałkanów Zachodnich. W związku z powyższym negocjacje toczą się w zakresie Wieloletnich Ram Finansowych na lata 2021-2027.

„Pomoc finansowa $\mathrm{w}$ dziedzinie środowiska i zmian klimatu była dotychczas głównie sektorowa, skoncentrowana na procesie dostosowania do dorobku prawnego UE zgodnie z wymogami rozdziału 27, z działaniami zarówno na poziomie dwustronnym (głównie inwestycje), jak i regionalnym (głównie budowanie zdolności). Biorąc pod uwagę kompleksowy charakter Zielonej Agendy, w nadchodzących latach należy skupić się na szerszych kwestiach zrównoważonego rozwoju gospodarczego, na dalszym uwzględnianiu kwestii ekologicznych w pomocy finansowej i wspieraniu wszystkich odpowiednich instytucji. W tej perspektywie zielona przysięga "nie szkodzić" i systematyka UE powinny być przestrzegane w możliwie szerokim zakresie. We wniosku dotyczącym Instrumentu Pomocy Przedakcesyjnej (IPA) III przewidziano wydzielone okno ram programowania na wdrażanie zielonej agendy i zrównoważonej łączności. Według projektu wniosku beneficjenci IPA będą zachęcani do rozwijania efektywności energetycznej i odnawialnych źródeł energii oraz do przechodzenia na zasoby oszczędne, bezpieczne i zrównoważone gospodarki niskoemisyjne zgodnie

10 Commission Staff Working Document. Guidelines for the implementation of the Green Agenda for the Western Balkans. Accompanying the Communication from the Commission to the European Parliament, the Council, the European Economic and Social Committee and the Committee of the Regions, An Economic and Investment Plan for the Western Balkans $[\operatorname{com}(2020)] 641$ final. 
z szerszymi celami UE w zakresie działań na rzecz klimatu i ochrony środowiska. Dzięki zrównoważonemu wykorzystaniu zasobów naturalnych nasi partnerzy mogą osiągnąć wyższe standardy ochrony środowiska i zdrowia ludzkiego oraz zwiększyć łagodzenie zmiany klimatu i przystosowanie się do niej. Przyniosłoby to nie tylko bezpośrednie korzyści zdrowotne i postawę obywatelską, ale także uczynienie regionu atrakcyjnym dla inwestycji i turystyki oraz wykorzystanie znaczącego potencjału gospodarczego zielonego wzrostu i gospodarki o obiegu zamkniętym. Komisja może również zbadać możliwość wykorzystania istniejących instrumentów pomocy finansowej do tworzenia lub wspierania szeregu instrumentów rynkowych w regionie, takich jak fundusz lub fundusze inwestycyjne kapitału naturalnego lub specjalne zielone okno w ramach projektów wspierających plan inwestycji zewnętrznych, które mają pozytywny wpływ na społeczność, środowisko, gospodarkę i środowisko, ale nie mogą uzyskać dostępu do tradycyjnego finansowania z powodu postrzeganego ryzyka. Albania, Czarnogóra, Macedonia Północna i Serbia będą nadal korzystać z wieloletnich programów rozwoju obszarów wiejskich w ramach Instrumentu Pomocy Przedakcesyjnej (IPARD). Programy IPARD zawierają zestaw 11 środków wybranych do realizacji przez partnerów. W ramach każdego z działań beneficjenci mogą uszeregować i wybrać sektory, które powinny otrzymać pomoc. Zrównoważone rolnictwo i produkcja żywności powinny być centralnym elementem IPARD w nowych World Resources Forum. Chociaż finansowanie IPA może wystarczyć do rozpoczęcia działań w kluczowych obszarach, podstawowe znaczenie będzie mieć wysokość finansowania ze strony innych zainteresowanych stron, w szczególności międzynarodowych instytucji finansowych (IFI). Europejski Bank Inwestycyjny, obecnie „bank klimatyczny" UE, musiałby grać wyraźną rolę w ścisłej współpracy z Komisją Europejską. Można również rozważyć utworzenie instrumentu wspierania reform strukturalnych, zapewniającego wsparcie na żądanie reform pobudzających wzrost. Komisja może również nadal korzystać ze sprawdzonych instrumentów łączonych i innowacyjnych instrumentów finansowych, aby zapewnić maksymalny wpływ. Ramy inwestycyjne dla Bałkanów Zachodnich (WBIF) są jednym z takich łączonych instrumentów finansowych, które mogą wspierać Zieloną Agendę. Działa już w sektorze ochrony środowiska i energetyki. W ramach nadchodzących wieloletnich ram UE ma oczekiwać, że WBIF zapewni dotacje inwestycyjne i budowanie zdolności w tych obszarach. W szczególności można dalej zmobilizować dwa 
istniejące obiekty łączące WBIF, skupiające się konkretnie na energii odnawialnej i efektywności energetycznej. Fundusz „Ekologia na rzecz Wzrostu” (GGF), zorganizowany jako partnerstwo publiczno-prywatne, może nadal zapewniać finansowanie zielonych inwestycji, podczas gdy Regionalny Program Efektywności Energetycznej (REEP) może wspierać transpozycję i wdrażanie dorobku prawnego UE w zakresie efektywności energetycznej $\mathrm{w}$ połączeniu z finansowaniem przedsiębiorstw, gospodarstw domowych i podmiotów sektora publicznego podejmujących inwestycje w efektywność energetyczną ${ }^{11}$.

„Najbardziej ambitną i konkretną spośród tych inicjatyw jest plan gospodarczy i inwestycyjny dla Bałkanów Zachodnich o wartości 9 mlrd euro, któremu towarzyszy Zielona Agenda dla Bałkanów Zachodnich (WE 2020d; WE 2020e). Obejmuje ona pięć filarów działania na rzecz klimatu: gospodarkę o obiegu zamkniętym, bioróżnorodność, walkę z zanieczyszczeniem powietrza i zrównoważone systemy żywnościowe. Zawiera pewne, aczkolwiek bardzo ogólne inicjatywy, podczas gdy Plan inwestycji gospodarczych dla Bałkanów Zachodnich obejmuje bardziej konkretne flagowe inwestycje, które Komisja Europejska zamierza zrealizować przed końcem swojego mandatu w 2024 r., w tym cztery bezpośrednio wchodzące w zakres Zielonej Agendy" ${ }^{\prime 2}$.

\section{Bałkańskie działania na rzecz Zielonej Agendy}

Przywódcy państw bałkańskich najszerzej wypowiedzieli się w zakresie działań proekologicznych już w ramach Deklaracji z Sofii na rzecz wdrażania Zielonej Agendy dla Bałkanów Zachodnich ${ }^{13}$. Główne założenie zostały

11 Commission Staff Working Document. Guidelines for the implementation of the Green Agenda for the Western Balkans. Accompanying the Communication from the Commission to the European Parliament, the Council, the European Economic and Social Committee and the Committee of the Regions An Economic and Investment Plan for the Western Balkans [COM(2020) 641 final].

12 C. Teevan, A. Medinilla, K. Sergejeff, The Green Deal in EU foreign and development policy.

13 Sofia Declaration on the Green Agenda for the Western Balkans, Regional Cooperation Council [online], II 2021: <https://berlinprocess.info/wp-content/uploads/2021/o2/Leaders-Declaration-on-the-Green-Agenda-for-the-WB.pdf $>$ [dostęp: 17 VII 2021]. 
ujęte w czterech głównych obszarach obejmujących kwestie klimatu, energii, mobilności; zapewnienia podstawowych standardów życia; gospodarki proekologicznej oraz zrównoważonego rolnictwa i produkcji żywności. Pierwsze z zagadnień dotyczących kwestii klimatycznych wyrażało zobowiązanie do działania na rzecz stworzenia neutralnej emisyjnie pod kątem dwutlenku węgla przestrzeni obejmującej takie sektory gospodarcze jak produkcja energii i transport, zwłaszcza eliminując ubóstwo energetyczne, lecz także wdrażając procedury mające na celu wprowadzenie rozwiązań prawnych wspomagających te działania, zgodnych zarówno z dorobkiem prawnym Unii Europejskiej, jak i ramami Wspólnoty Energetycznej. Jednocześnie uznano, że jednym z najważniejszych elementów jest przygotowanie się na ewentualne zmiany przede wszystkim poprzez zdolności akomodacji i adaptacji do zastanej rzeczywistości. Takie podejście ma na celu rozwijanie zdolności reedukacji występowania zagrożeń naturalnych, katastrof naturalnych, a po ich ewentualnym wystąpieniu radzenia sobie z nimi, a także stworzenia regionalnych inicjatyw odzwierciedlających wspólnotowe podejście w ramach Europejskiego Paktu Klimatycznego. Ponadto za kolejny kluczowy cel uznano nabycie zdolności do wejścia w unijny czy też europejski system dystrybucji i wymiany oraz ustanawiania cen i partycypacji w emisji dwutlenku węgla. $Z$ tymi działaniami powiązano jednocześnie konieczność weryfikacji zmian, jakie mogą zachodzić w aspekcie społecznym i gospodarczym, ich wpływu na struktury gospodarcze i poszczególne społeczności lokalne oraz wypracowanie mechanizmów i narzędzi pozwalających na zapobieganie negatywnym skutkom działań proekologicznych, w tym także zmian w strukturze gospodarek poszczególnych państw, przy zachowaniu unijnych zasad udzielania wsparcia, zwłaszcza krajowego. Kolejnym znaczącym elementem działania w ramach ustanawiania Zielonej Agendy dla Bałkanów, wpisującej się w założenia Zielonego Ładu jest niewątpliwie dążenie do rozwijania inteligentnych gospodarek, wspieranie nowoczesnych, innowacyjnych technologii oraz dynamizowanie i zacieśnianie współpracy regionalnej i międzyregionalnej, szczególnie poprzez tworzenie tzw. zielonych korytarzy. Podobne działania, choć nieujęte $\mathrm{w}$ takie ramy definicyjne, podejmowano już wcześniej, choćby podczas prób rozwijania funkcjonalnej współpracy regionalnej na Bałkanach, np. działania na rzecz czystości i efektywnego korzystania z zasobów Jeziora Ochrydzkiego. „Zobowiązano się do pracy nad zdefiniowaniem ram różnorodności biologicznej po 2020 r. i opracowania długoterminowej strategii powstrzymania utraty różnorodności 
biologicznej, ochrony i odbudowy ekosystemów i obfitej różnorodności biologicznej, w szczególności poprzez następujące działania: opracowanie i wdrożenie strategicznego planu na rzecz różnorodności biologicznej 2030 dla Bałkanów Zachodnich, obejmującego środki na wspólną realizację, monitorowanie i sprawozdawczość; przygotowanie planów ochrony i odtwarzania przyrody, w tym dla obszarów morskich; opracowanie i wdrożenie planu przywracania krajobrazu leśnego Bałkanów Zachodnich; analizowanie korzyści związanych z różnorodnością biologiczną wynikających z rozwiązań opartych na przyrodzie i możliwości ich włączenia do rozwoju planów klimatycznych i innych; wzmocnienie mechanizmów współpracy regionalnej i planowania strategicznego $\mathrm{w}$ zakresie ochrony różnorodności biologicznej oraz realizacji zobowiązań wynikających z Konwencji o różnorodności biologicznej, takich jak grupa zadaniowa ds. różnorodności biologicznej w Europie Południowo-Wschodniej. Wzmocnienie zaangażowania w konwencje ONZ z Rio i wspólne wysiłki na rzecz przygotowania regionalnego stanowiska w sprawie globalnej agendy różnorodności biologicznej po $2020 \mathrm{r}$. zgodnie ze strategicznymi celami UE; poprawę i wymianę wiedzy, w tym gromadzenie, zarządzanie i dostępność informacji na temat różnorodności biologicznej i ochrony przyrody, zacieśnienie partnerstwa między centrami badawczymi oraz istniejącymi platformami, a także zbadanie możliwości utworzenia Centrum Informacji o Różnorodności Biologicznej Bałkanów Zachodnich"14. Deklaracja z Sofii stała się podstawą do wypracowania kolejnych założeń dotyczących m.in. krajowych planów na rzecz energii i klimatu, projektów przeciwdziałania ubóstwu energetycznemu, tworzenia kolejowych korytarzy transportowych ograniczających transport samochodowy oraz jednego $\mathrm{z}$ najważniejszych, $\mathrm{tj}$. kreowania inteligentnych miast. Ponadto w związku z Traktatem Wspólnoty Energetycznej ${ }^{15}$ Kosowo, Serbia, Macedonia Północna oraz Bośnia i Hercegowina podjęły się wykorzystania możliwości funkcjonowania w ramach Narodowego Planu Redukcji Emisji, przede wszystkim w celu redukcji zanieczyszczeń, odnosząc się jednocześnie do europejskiej dyrektywy w sprawie emisji przemysłowych.

14 Tamże.

15 Decyzja Rady z dnia 29 maja 2006 r. w sprawie zawarcia przez Wspólnotę Europejską Traktatu o Wspólnocie Energetycznej (2006/500/WE), „Dziennik Urzędowy Unii Europejskiej", L 198/15 [online], 20 VII 2006 [dostęp: 20 VII 2021]: <https://eur-lex. europa.eu/legal-content/PL/TXT/PDF/?uri=CELEX:32006D0500\&from=PL $>$. 


\section{Bibliografia}

Commission Staff Working Document, Guidelines for the implementation of the Green Agenda for the Western Balkans. Accompanying the Communication from the Commission to the European Parliament, the Council, the European Economic and Social Committee and the Committee of the Regions An Economic and Investment Plan for the Western Balkans [Cом(2020) 641 final].

Decyzja Rady z dnia 29 maja 2006 r. w sprawie zawarcia przez Wspólnotę Europejską Traktatu o Wspólnocie Energetycznej (2006/500/WE), „Dziennik Urzędowy Unii Europejskiej", L 198/15 [online], 20 VII 2006 [dostęp: 20 VII 2021]: <https://eur-lex.europa.eu/legal-content/PL/TXT/PDF/?uri=CELEX:320 06D0500\&from $=\mathrm{PL}>$.

Europejski Zielony Ład, Komisja Europejska, Przedstawicielstwo w Polsce [online], 11 XII 2019 [dostęp: 17 VII 2021]: <https://ec.europa.eu/poland/ news/191211_green_deal_pl>.

From where do we import energy??, Eurostat [online], 3 II 2021 [dostęp: 17 VII 2021]: $<$ https://ec.europa.eu/eurostat/cache/infographs/energy/bloc-2c.html\#carousel Controls?lang=en $>$.

Komunikat Komisji Parlamentu Europejskiego, Rady Europejskiej, Rady, Komitetu Ekonomiczno-Społecznego i Komitetu Regionów Europejski Zielony $a \mathrm{~d}, \operatorname{com}(2019) 640$ final, Komisja Europejska, Bruksela 2019, s. 2: $<$ https://eur-lex.europa.eu/resource.html?uri=cellar:b828d165-1c22-11ea-8c1fo1aa75ed71a1.0016.02/DOC_1\&format=PDF> [dostęp: 17 VII 2021].

Komunikat Komisji Parlamentu Europejskiego, Rady, Europejskiego Komitetu Ekonomiczno-Społecznego i Komitetu Regionów, Plan gospodarczo-inwestycyjny dla Batkanów Zachodnich, [SWD(2020) 223 final], Bruksela, 6 X 2020, $\operatorname{COM}(2020) 641$ final.

Leonard M., Pisani-Ferry J., Shapiro J., Tagliapietra S., Wolff G., The geopolitics of the European Green Deal, "Policy Contribution" 2021, Issue 04: <https://www. bruegel.org/wp-content/uploads/2021/o2/PC-04-GrenDeal-2021-1.pdf> [dostęp: 21 VII 2021].

Sofia declaration on the Green Agenda for the Western Balkans, Regional Cooperation Council [online], II 2021: <https://berlinprocess.info/wp-content/ uploads/2021/o2/Leaders-Declaration-on-the-Green-Agenda-for-the-WB.pdf $\rangle$ [dostęp: 17 VII 2021].

Teevan C., Medinilla A., Sergejeff K., The Green Deal in EU foreign and development policy, European Centre for Development Policy Management, Maastricht 2021 (Briefing Note, No. 131): 〈https://ecdpm.org/wp-content/uploads/GreenDeal-EU-Foreign-Development-Policy-ECDPM-Briefing-Note-131-2021.pdf $\rangle$ [dostęp: 17 VII 2021]. 